\title{
高周波加熱のプラスチツク及びゴムエ業に 於ける應用
}

まとして V:W. Sherman : Dielectric Heating.(Modern Plastics, 1945, Nov.) A. R. Tinnerhohn: High Frequency Pre-heating (Modern Plastics, 1946, April)

H. A. Leduc: The Application of High Frequency Current in the Rubber Industry Proceçdings of the Rubber Technology Conference, 1938 p. 381 の紹介

東京工業大學ゴム研究屴 早 田喜 望

\section{1. 緒䨐}

可塑物、ゴム、繊維、食品等の熱傳導の少ない物質に對する加熱の万法として最近誘電加熱(Dielectric Heating) 節ち高周波加熱 (High-Frequency Heating)の方法の研究が淮み决第に寞用化される棦になつ て來て居る。此の方法が研究される以前には蒸氣加熱、赤外線照射等が用ひられて居た。之等の方法に よる加熱では單に表面より加熱するのみに止り、明かに次の如き缺點が考へられる。

（1）加熱が徐々に行はれ而も其の溫度は型の表面溫度の限度により制的される。

（2）表面と內部とには相當の溫度勾配がすり之が篇に加熱が均一に行はれない。

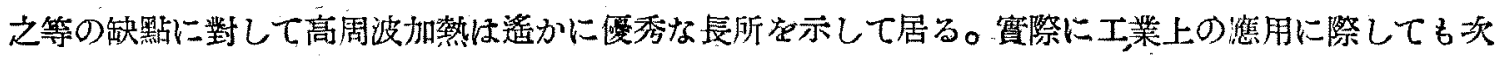
の如き點は興味がある。

（1）物質全體在通じて加熱が均一に起方事。

(2) 加熱の速度が速い事。

此の二つの爲に從來の方法によつて生じた慗品の化學的、物理的不均一さを避ける事が出來る。

高周波加熱の工業上の應用は誘電體損失の利用にある。笔導度の小さい物質を高周波の電場に䀧す事 によつて、物質の各分子はその周波數に應じて反轉し難くなり、その䉆に熟在發生する。發生した熱は 各分子が歪みや再配直に對抗する磨擦力によつて生じた誘電的エネルギーである。

\section{2. 高周波加熱の經濟的畫義}

今ブラスチック、ゴム、合成ゴム工業分野に於ける高周波加熱の經濟的重要性は直接生虐能力虎增大 すると同時に、間接的にも土場維持費、蒸穼發生、床面皘の費用等を節約する事が出來る。之等の點に ついては更に完全な經码的研究が必要である。

ブラスチックエ業に於ては高周波加熱は長期間期待されて居た要求への直接の大きな返答ですつた。 過去多年に耳直つて、成型物艮所要の形に成型する篇には、高溫と高㻺とが必要ですつた。例へば塺力は 
500 ton にる及んで居り、成型とサマシに要する時間は全部で 30分乃至は 40分をも要した。

かつる場合に祭しで高周波加熱农適用すれば成型は簡單であり、而る容易に篇されるのである。一B

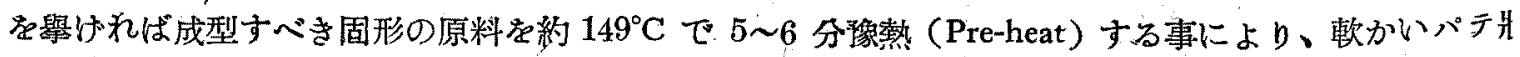

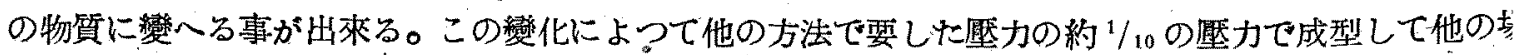
合と同樣の結果学得る事が出來る。

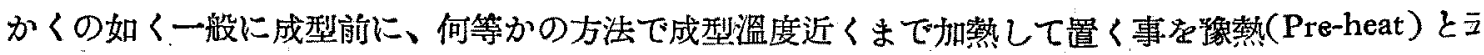
ふ。今この像熱について少し述べて見やう。成型技術者にとつて今日までに最も大きな難關とされて㕆 たのは、大ぎな成形物殊にボロる充填劑とした熱硬化性可塑物ひ成型で西つた。處が高周波加熱を用て れば以新は成型の困難であつた樣な形の複雜な或ひは大きな成型も非常に簢單に解決されて居る。

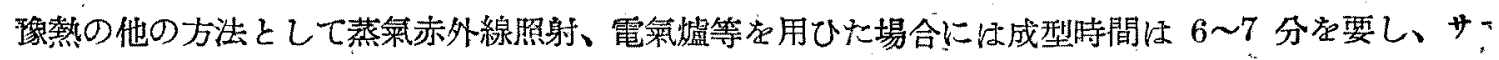
シの時閏学加へると45分にも及んで居た。

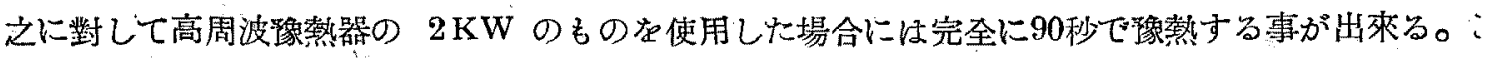

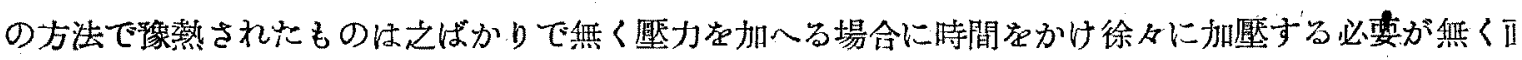
ちに高壓で成型し得る。

捼入ピン（成型材の穴のある場合、其の部分に動め插入して置くピン）のあるもの>成型品でも高原

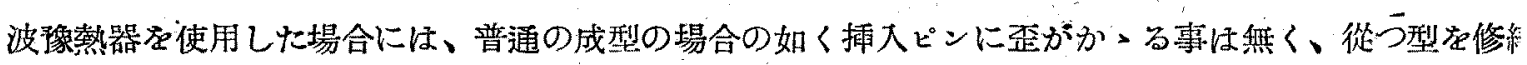

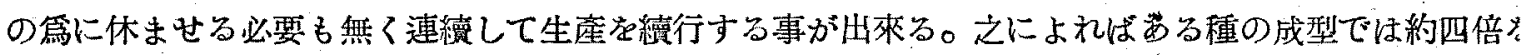
生產する事が出來る。

高周波鞇熱が使用された場合にはバリの削りも以前の $1 / 4$ に繀減されるので仕上げも亦容易となる。 要するに仕上けの外觀が遙かに淮步した譯である。

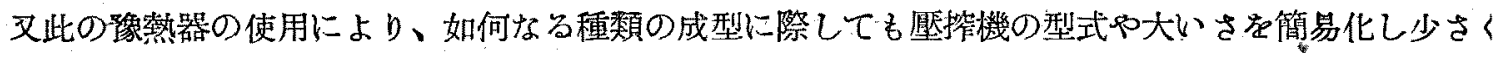

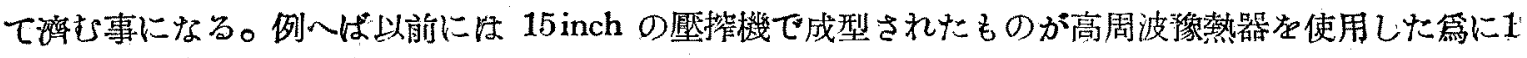

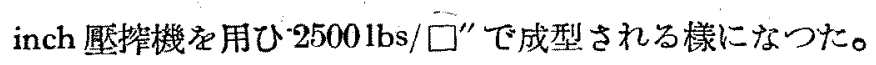

プラスチック工羍、ゴム工業に於ける高周波加熱裝置の價格は主として其の出力につき計算される。 例へば $1 \mathrm{KW} 2000 \$ / \mathrm{KW}$ に及゙ものから $25 \mathrm{KW} て ゙ ~ 500 \$ / \mathrm{KW}$ 等に至つて居る。

\section{- 3. 今後の發展方向}

プラスチック工業に於ては高周波豫熱の利用は少くともこつの 大きな發展方向它示して居る。

（1）型の大きい成型品の生産が完全に行はれる樣になつた。

(2) 緻密なる聥人物のる精確な複雜な型の成型る出來然も 相當の厚さの變化に對しても影響が少ない點でする。

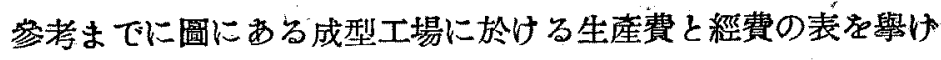
他の豫熱方法を用ひた場合をを比較して見よゔ。他の像熱力法に

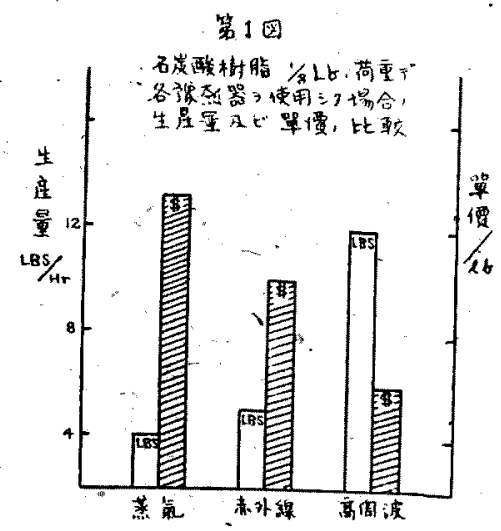


哺ける加熱方法注次の如くである。

（1）蒸爰による加熱——此の場合では熱は水蒸氣を通じた型の表面より傅導せられる。

（2）赤外線照射—此の場合には成型材料は型に入れる前に表面照射法により嶑熱される。

何れの場合でも加熱方法は高周波利用の場合上りる時間を要し原料の內部と外部とに相當の溫度勾欺 ・が見られーる。

高周波豫熱法はボタンの如き簡單な成型品の成型に利用しても無意味でする。何故ならば此の場合に は表面からの加熱が完全になされる嫣に結局潒熱による利谷は何等現れて來ないからである。

\section{4. 加熱裝置に就て}

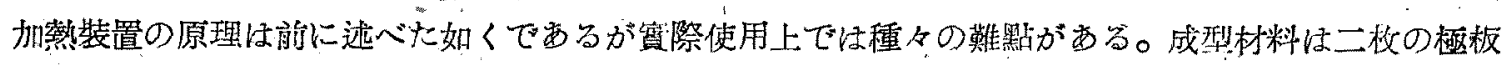
の間に挾み、電極ほ高周波發生裝置に接續して居る。總ての場合に加熱に際してて成型材料が熱により 膨脹するので之に對する處置を取らねばならぬ。其體的には次の栐なす法が行はれて居る。

1. 膨脹に備へる篇に充分な大いさの隙間在作るさと。

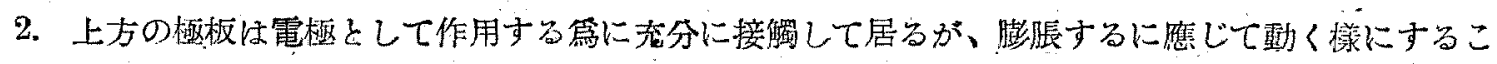
之o

高周波加熱は所謂低壓成型出出來る。此の場合でも多くの插大ピンの方省複雜な输郭の成型も容易心

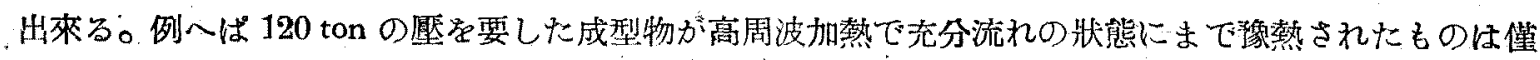
かに 35 ton で完全に成型される核な場合もある゙。

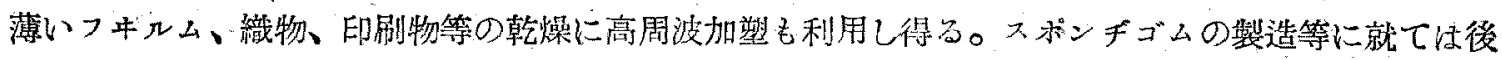
に述べっ事にする。

\section{5. 高周波加熱に用ひられる周波數}

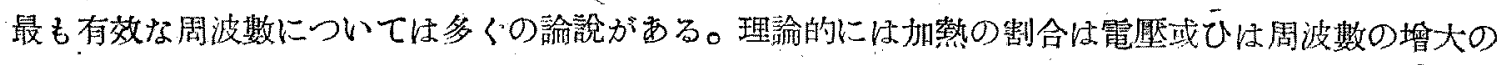

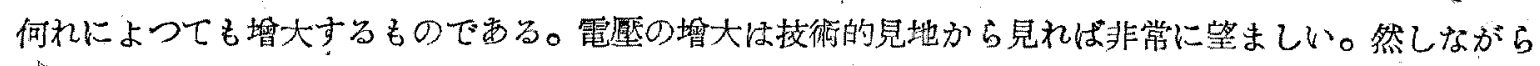

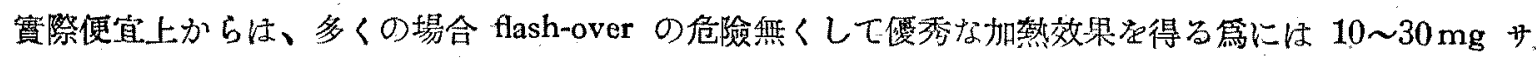
イクルの周波數が必要である。

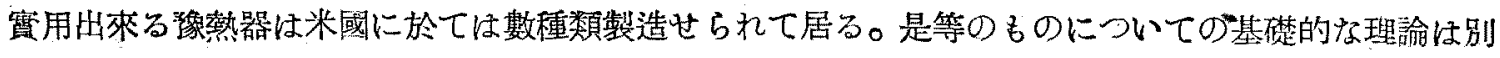
として實際の設計使用上に用ひられる数式舉げれは次の如きものがする。

\section{(1) 所要荍量}

$=$ 比熱 $\times$ 試料の重量(pound) $\times$ 溫度 $\mathrm{F}^{\circ}=\mathrm{Btu}$.

(2) 所要電力

$$
=\frac{\text { Btu. }((1) \text { によ計算せられた值 })}{1.05 \times \text { 所要加熱時間 }}=\mathrm{KW}
$$

(3) 所要の試料、厚さ (inch)に對する絠厴 
$=26500 \sqrt{\frac{\text { KW((2)により計算せられれた值) }}{\text { 誘電體損失率 } \times \text { 面積 }\left(\square^{*}\right) \times \text { 周波數 }}}=$ volt

一例へばフエノール樹脂 $8^{*} \times 8^{*} \times 1 ", 2$ pound の試料（比熱 0.35 ; 誘電體損失率 0.3 ) 在 $3 \mathrm{KW} の$ 出

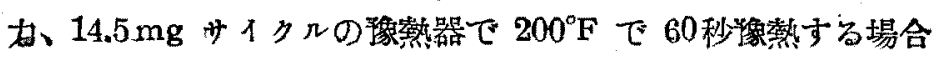

(1) 全熱量 $=0.35 \times 2 \times 200=140 \mathrm{Btu}$.

(z) 電 $力=140 / 60=2.3 \mathrm{KW}$

(3) 電 壓 $=26.500 \sqrt{\frac{2.3}{0.3 \times 6.4 \times 14.5}}=2410$ volts

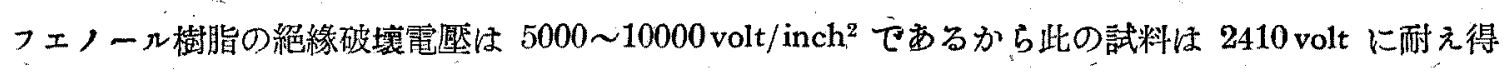
万。

\section{6. コム工業への高周波加熱法の應用に就て}

ゴムは其の熱傅導性の不良の爲に工業上殊にスポンヂゴム工業上に多くの困難なる事實が多かつた。 此の熱傳導性の不良な物質の加勢力法として高周波電流の利用が研究されたのである。

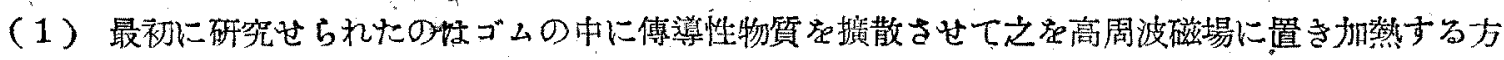

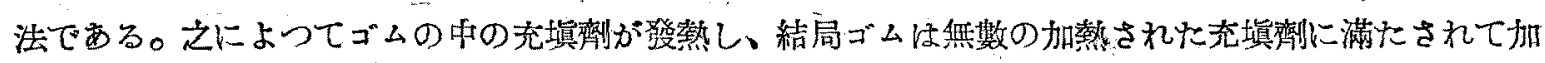

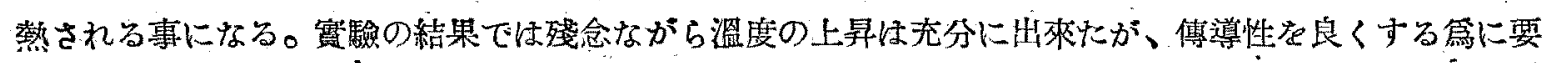
さる金屬或仕金屬化合物の粒子の量は相掌量である事がわかつた。

例へばアルミニウム粉末、カーボンブラッタ、硫化亞鉛等の微粒子を冭分に搌散せしめた場合 50000 〜100000 サ1ク几の周波數では溫度の上昇は 1 時間に $5 \sim 6^{\circ} \mathrm{C}$ 程度である。鐵粉で粉子の大Wさ $0.3 \sim$ $0.5 \mathrm{~mm}$ 程度のるの含 $10 \%$ 含んだゴムの場合には溫度の上昇は上り早くなる。，

然しながら是等の場合には成型品の表面と中心とには未だ相當の溫度勾配がする事がかかつた。例人

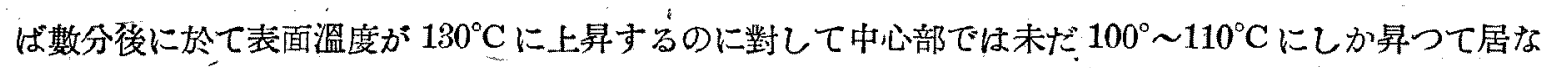
い。以上の如き缺點が多い掌に此の研究は以後中絕されるに至つたのである。

（2）上达の方法の實際的應用が不可能になつた夙に次に誘電體損失による規則正しい而も相當溫度 上昇の速い加蓺方法が研究される樣になつた。最近では此の方面の研究は主として工業方面八の應用例 へばゴム張り金屬ロール等の加硫へ向けられて來て居る㥞でする。

若し電場に與へられる電界强度と周波數が充分に大きければ一例へば $10 \mathrm{mg}$ サイクル程度ですれ ば——多くの誘電體は早く加熱せられる事住知られて居る。此の方面の研究についてはゴムに關する研 究が多く報告されて居ま。

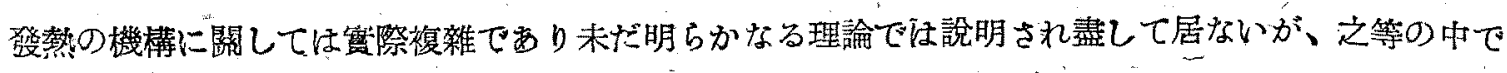
は Wagner, Debye の理論が良く說明されて居る。一般のゴム理論家としては次の如き事雷知つて置 く必要がすらう。

（1）均一は誘笔體が均一なっ高周波の霄場に置かれた場合には物質の發熱は均一に行はれる。 
（2）吸收されるエネルギー云ひ换へれば溫度の上昇は周波と電界强度に比例して增大寸る。

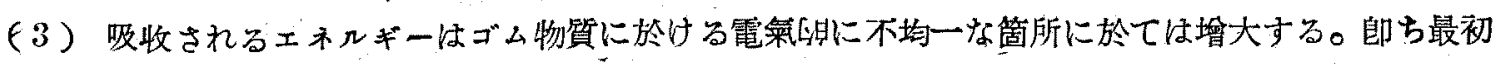
の物質單獨ではェネルギー吸收の少はい場合でも若干比感應度(Specific Inductivity)の大きな 物質を少量混大すると之が爲にエネルギ、吸收を增大する結果となる。

誘電損失必堌大する物質としてはカーボンブラック、亞鉛華、硫化亞鉛等が知られて居る。この新ら しい方法ではゴムの熱傳導性は大して問題にはならない。それ故に厚いゴム板の加硫でも普通の薄いも のと同樣に簡單に出無るのである。

(3)，筫際的應用方面

大別して生ゴム、スモークシート、ペールクレープよりゴム製品製造に用ひ場合とラテックスより の製造に用ひる場合とがある。

前者の場合に於ては生ゴムの加硫、スボンヂゴム、厚板、ローラーの成型等があり、媵些の場合には ラテックスの濃縮等がある。大體 $1 \mathrm{~kg}$ の配合ゴム $140^{\circ} \mathrm{C}$ で加硫するのに高周波在利用すれば 200〜 $300 \mathrm{Wt} / \mathrm{Hr}$ の電力在要し縃濟的にも穓用可能である。

a) スポンヂゴムの製造

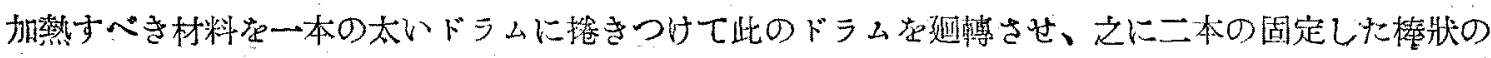
電極觉ドラムの軸と平行に置いて接觸させる。此の場合 $20 \mathrm{~cm}$ 以上の物ても加熱が均一に行はれ其の內

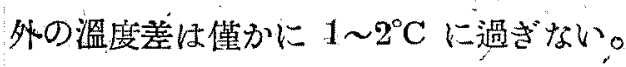

b) 成型

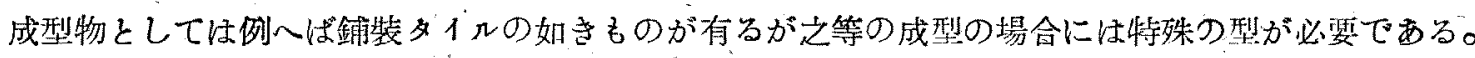

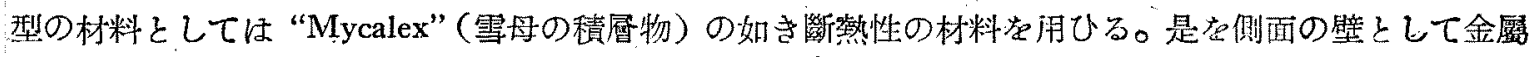
の二枚の板を上下より梗板として作用させる。“Mycalex”の側壁は金屬の帶で㗭きしめられる。上なの 極板はと゚ントンの作用をなして成型する事になる。

“c) ラテックスへの應用

ラテックスの濃緛、殺菌、加硫等にる高周波加熱住利用される。特に興味する問題として熱感受性

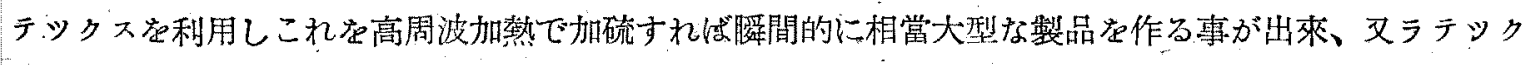
ス糸の凝固、紡夈、或はラテックス被稪線の表面凝固加硫等にも直接に使用される。此の方法は非常に 經濟的でも西り、例へば $100 \mathrm{~W}$ の高周波發振器在用ひ每秒數メートルの速度で15〜20箇のノヅルから 徑 $1 \mathrm{~mm}$ のラテックス系虏引き出して凝固させる事が出來る。

\section{7. 結語}

以上甚だ斷片的なデーターの聚集に過ぎないが、要するに高周波加熱のブラスチック工莱への利用に 於ける大なる利點を要約すれで知の如くでする。

(1) 生庰の间上

a) 放冷の時間が 4/5に縮減せられる。 
b) より小さいプレスでより早く成型し得る。

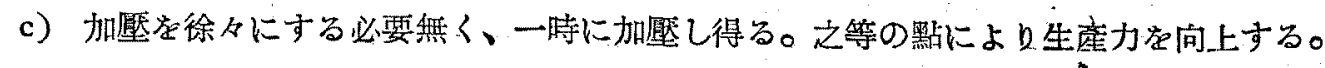

(2) 修綁の少ない事

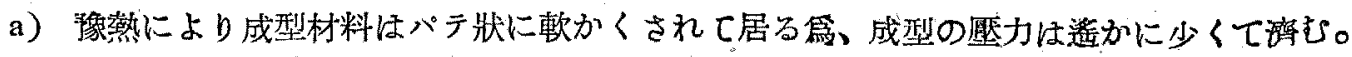

b）小さい型で少ない壓力で成型し得る。

(3) 成型材料の節約 バリが $1 / 4$ に縮減される爲である。

(4) 廢品が少ない事

（5）仕上げの費用が少ない

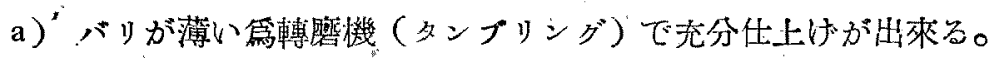

b）複雜な形の慗品でるバフて簡單に仕上げが出來方。

（6）普通の成型洪では出來なかつたものも容易に成型せられ從つて特殊な装置を两せすしで複雊な 成型虎店し得名。

（7）ボロ在充䁲せる成型材複䬱な型の成型等が容易に出來る。

(8) 外觀がより改善される。

ゴム工篻に於ては高周波加熱の利用はプラスチック工等に於ける程は未だ普及しては居ないが、種々 の興味西る特徽があり、今後普及す方可能性洼充分に見られる。，

以上の如き多くの利點在持ち而も經濟的にも有利であるので高周波加熱法は今や賽驗宝の款破り坎， 第に工業分野への地盤㾜固わるに至つたのでする。

\section{ゴム製造に於ける熱の問題}

まとして Stuort H. Hahn: Thermal Problems in Rubber Manufacture. (Journal of Applied Physics. 1941, 12, No. 1. 12) の紹介

東京工業大學ゴ么研究室 筫 浦 有 二

\section{1. 緒 論}

ゴム工業の基礎的作業でする加硫 (Vulcanization) は一Vulcan が火の神の名で、それに因みつけら れた樣に一一溫度と非常な關係がある。ゴム活熱非傳導體である故、近代文明の要求する巨大な製品虑

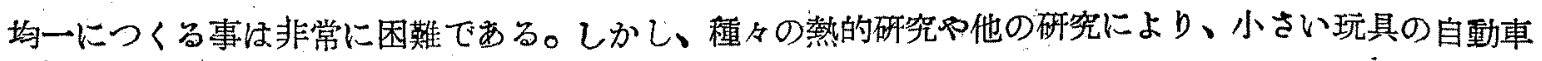

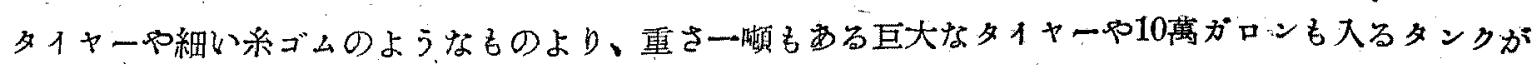
彆造される粶になつた。

加硫作業までのゴムの種かの工程にる多くの熱に閶する問題が存在して居当。素練り、混合、押出し 